\title{
Carbon Stock Density of the Different Carbon Pools in Tulu Lafto Forest and Woodland Complex: Horo Guduru Wollega Zone, Oromia Region, Ethiopia
}

\author{
Fekadu Gurmessa ${ }^{1}$, Bikila Warkineh ${ }^{2}$, Sebsebe Demissew ${ }^{2}$, Teshome Soromessa ${ }^{3}$ \\ ${ }^{1}$ Department of Biology, College of Natural and Computational Sciences, Wollega University, Nekemte, Ethiopia \\ ${ }^{2}$ Department of Plant Biology and Biodiversity Management, Addis Ababa University, Addis Ababa, Ethiopia \\ ${ }^{3}$ Center for Environmental Science, Addis Ababa University, Addis Ababa, Ethiopia
}

Email address:

fekadugurmessa.2020@gmail.com (F. Gurmessa)

\section{To cite this article:}

Fekadu Gurmessa, Bikila Warkineh, Sebsebe Demissew, Teshome Soromessa. Carbon Stock Density of the Different Carbon Pools in Tulu Lafto Forest and Woodland Complex: Horo Guduru Wollega Zone, Oromia Region, Ethiopia. European Journal of Biophysics.

Vol. 9, No. 1, 2021, pp. 37-47. doi: 10.11648/j.ejb.20210901.16

Received: March 18, 2021; Accepted: May 21, 2021; Published: May 31, 2021

\begin{abstract}
Forest contains one of the world's largest terrestrial C pools and play vital role in combating climate change through carbon sequestration. This study was conducted on Tulu Lafto Forest and woodland complex (here after named as TLF) with the objective of investigating carbon stock density of the different carbon pools and its variation between vegetation units. Data were collected from a total of 75 nested plots. Diameter at breast height and total height were measured for all woody individuals (trees, shrubs and lianas) that attained a DBH of $2.5 \mathrm{~cm}$ and above. Woody plants that did not attained a DBH of $2.5 \mathrm{~cm}$ and herbaceous plants were destructively harvested from subplots of $1 \mathrm{~m}^{2}$ within the main plot. All dead woods were also measured for their length and diameter and samples were taken to determine its specific wood density and decomposition class. Above and below ground biomass was estimated using allometric equation, while the litter carbon was determined by loss on ignition (LOI) method. Soil samples were also collected in order to determine soil organic carbon. The mean above and below ground $\mathrm{C}$ stocks were 218.4 and $43.49 \mathrm{t} \mathrm{C} \mathrm{ha}^{-1}$, respectively while, $\mathrm{C}$ stocks in soil organic matter, dead wood and litter were $128.95,6.15$ and $2.43 \mathrm{t} \mathrm{C}^{-1}$, respectively. The total C stock density of TLF was found to be $399.42 \pm$ $265.15 \mathrm{t} \mathrm{C} \mathrm{ha}^{-1}$ of which 54.68 and $32.28 \%$ was kept in the aboveground biomass and soil, respectively. Result indicated that there is significant $C$ stock density variation between vegetation units in the study area.
\end{abstract}

Keywords: Tulu Lafto Forest and Woodland Complex, Aboveground Carbon, Forest Carbon Pools, Carbon Stock Density Variation

\section{Introduction}

Climate change is a widespread and growing concern of the global community. As a result, the role of tropical forests in mitigating the impact of climate change through increased $\mathrm{CO}_{2}$ uptake has got global recognition [42]. Thus, determining forest biomass and its $\mathrm{C}$ content is essential to understand the global $\mathrm{C}$ budget and the amount of $\mathrm{C}$ that would be released from converting a forest to cleared land (and vice versa) [38]. While plants are absorbing atmospheric $\mathrm{CO}_{2}$ to make their food, enormous amount of carbon is sequestered and stored in forest biomass $[44,55]$. This made forests key component in the processes of mitigating the impacts climate change [24, 29, 41]. Recently, international communities are working towards reducing greenhouse gas emissions while increasing their sinks, especially that of $\mathrm{CO}_{2}$ [31]. As a result, the forest area designated for $\mathrm{C}$ storage purpose in the world is increasing from time to time mainly due to their low cost. For example, the forest area designated for similar purpose has increased from $1.3 \%$ in 1990 to $5.3 \%$ in 2015 [51]. However, the $\mathrm{C}$ storage potential of forests is deteriorating from time to time due to human induced deforestation and forest degradation especially in Africa and South America [42]. Although net annual emissions from deforestation is decreasing from annual average of $4.68 \mathrm{Gt}$

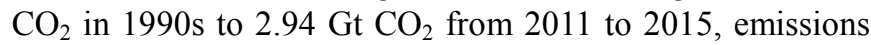


from forest degradation is increasing three-fold, from $0.35 \mathrm{Gt}$ during 1990 s to $0.99 \mathrm{Gt}$ in 2011-2015 [23] suggesting a sudden shift in $\mathrm{CO}_{2}$ emission from deforestation to forest degradation.

As deforestation and forest degradation are continuing to be significant sources of $\mathrm{CO}_{2}$, documenting forest $\mathrm{C}$ stock and measuring its change through time is among the crucial steps in mitigating the impact of climate change. This could support regulatory frameworks such as the United Nations REDD program on the one hand and national policies that could enhance forest $\mathrm{C}$ stock on the other hand. Reducing emission from deforestation and forest degradation and increasing forest area through afforestation and carbon management in the existing forests could offset as much as $10-20 \%$ of fossil fuel-based emissions [48]. Thus, accurate and timely monitoring of forest biomass and its carbon content is vital for investigating changes in forest $\mathrm{C}$ stocks at global level. But these are not comprehensive in developing countries mainly Africa [8, 17, 59]. Like other African countries, measurement of forest biomass and its $\mathrm{C}$ stock is at its early stage in Ethiopia with only few efforts started recently $[3,4,9,33,34,53,64,66,67]$.

Ethiopia consists of 12.3 million ha of forest land [20] which provide important $\mathrm{C}$ sink. But, regular forest resource assessment is absent and forest $\mathrm{C}$ stock estimation is fragmentary and showed wide variation in the country. Insufficient biomass and $\mathrm{C}$ storage data in Ethiopian forests makes it difficult to evaluate the $\mathrm{C}$ sequestration potential of forests in the overall climate change mitigation efforts. In Ethiopia, the mean $\mathrm{C}$ stock in the living biomass showed huge variation, ranging from 25 ton $\mathrm{ha}^{-1}$ (for AcaciaCommiphora woodland) to 125 ton $\mathrm{ha}^{-1}$ (for Moist Afromontane forest) [22]. Available literature also revealed inconsistency in total forest $\mathrm{C}$ stock at national level. Yitebitu Moges et al. [67] reported about 2.76 billion tons of $\mathrm{C}$ while FAO [22] reduced it to only 219 million tons. This variation could be due to differences in sampling method and the allometeric models used in biomass estimation.

TLF is one of the few remnant forest patches with natural vegetation cover in Ethiopia. It plays key ecological roles including biodiversity conservation and $\mathrm{C}$ sequestration, but no detailed scientific study was made to document the $\mathrm{C}$ stock density of the different carbon pools in TLF. So, this research was conducted with the following objectives in mind: (1) to estimate the amount of carbon accumulated in all carbon pools, (2) to investigate the $\mathrm{C}$ stock variation among the different vegetation units and (3) to provide base line data for $\mathrm{C}$ monitoring on a regular basis.

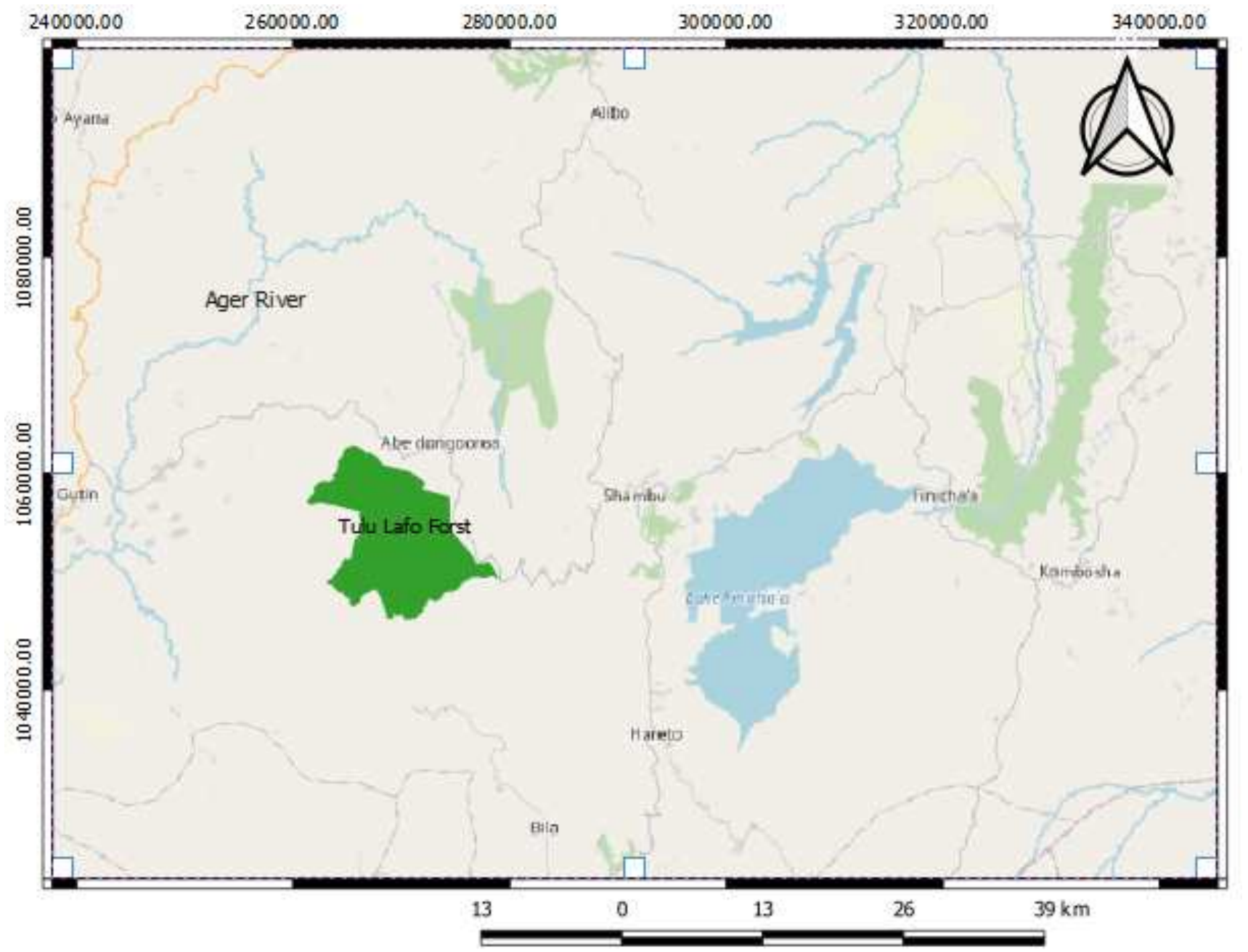

Figure 1. Map of Study area (TLF). 


\section{Materials and Methods}

\subsection{Study Area}

TLF is located at a distance of $378 \mathrm{~km}$ west of Addis Ababa and $59 \mathrm{~km}$ from Shambu (Horo Guduru Wollega zone capital) in Abe Dongoro district of Horro Guduru Wollegga zone, western Ethiopia between $9^{\circ} 27^{\prime}$ to $9^{\circ} 37^{\prime} \mathrm{N}$ and $36^{\circ} 47^{\prime}$ to $37^{\circ} 00^{\prime} \mathrm{E}$ (Figure 1). The study area is found on a steep and isolated mountain that is surrounded by lowland plains. The forest boundary covers an area of more than 10,000 ha with a wide gradient in elevation.

As the study area falls in the western highlands of Ethiopia, the rainfall pattern is unimodal. Climate data was obtained from

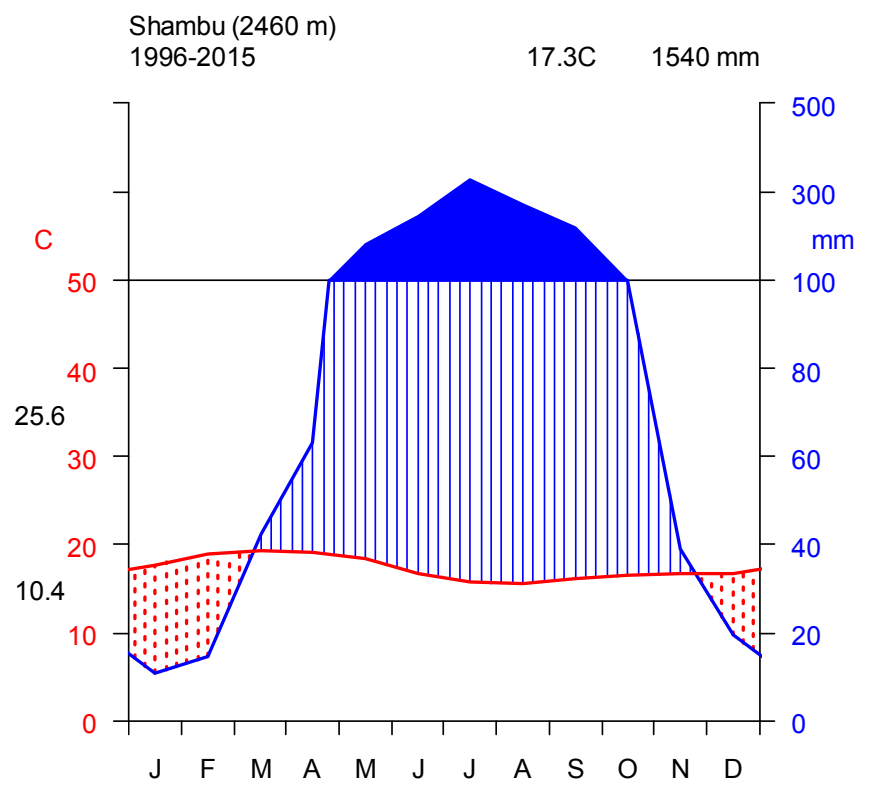

two nearest meteorological stations, Shambu and Anger Gutin (Figure 2). Shambu (2460m), in the east, has an average annual rainfall of $1540 \mathrm{~mm}$ and an average annual temperature of $17.3^{\circ} \mathrm{C}$. Angar Gutin $(1350 \mathrm{~m})$, in the west, has a mean annual rainfall of $1596 \mathrm{~mm}$ and an average annual temperature of $22.1^{\circ} \mathrm{C}$. TLF is dissected by numerous rivers and small streams that permanently feed Anger River. The forest is thus among the headwater sources of the Anger-Didessa watershed which is the main tributary to the Blue Nile River. Tulu Lafto forest consists of different vegetation units with rich floristic diversity. The tall savanna grasses mixed with short and medium sized trees predominate the elevation below $1500 \mathrm{~m}$ while dense canopy forests dominate the hill and far down stream areas.

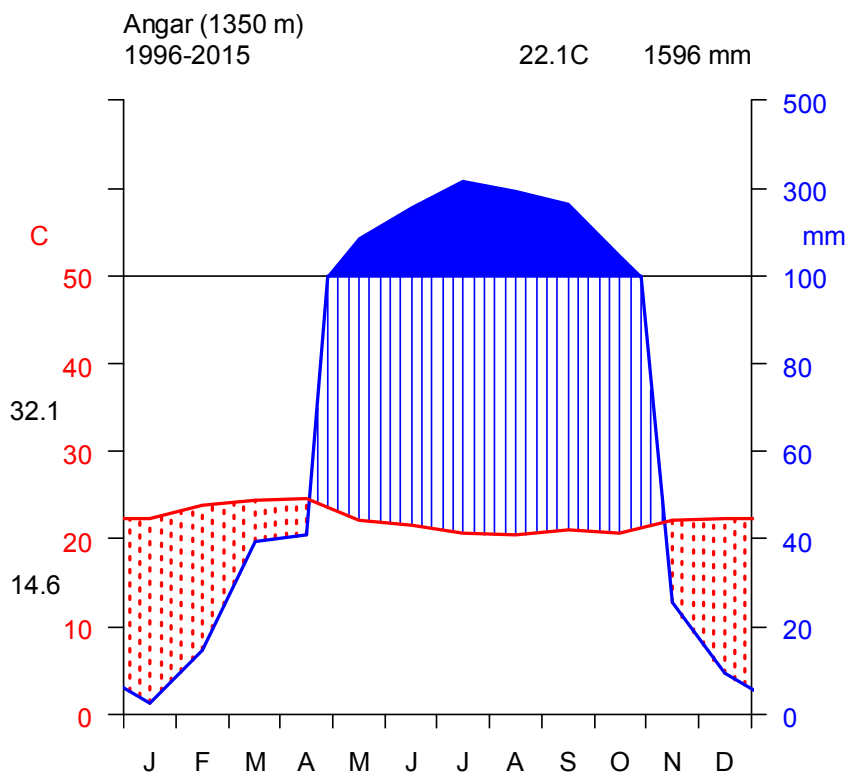

Figure 2. Climatic diagram of the study area.

\subsection{Data Collection}

In order to increase the accuracy and precision of measuring and estimating $\mathrm{C}$, it is useful to divide the study area into subpopulations or "strata" that form relatively homogenous units. TLF was divided into 3 vegetation units (CombretumTerminalia woodland type, Riverine type and Afromontane type) based on the dominant tree species and elevation in order to facilitate field data collection and increase the accuracy and precision of measuring $\mathrm{C}$ stock following Pearson et al. [56]. Nested plots of $400 \mathrm{~m}^{2}(20 \mathrm{~m} \times 20 \mathrm{~m}), 100 \mathrm{~m}^{2}$ (10 m x $\left.10 \mathrm{~m}\right)$ and $25 \mathrm{~m}^{2}(5 \mathrm{~m} \times 5 \mathrm{~m})$ were set to record trees with $\mathrm{dbh} \geq$ $30 \mathrm{~cm}$, dbh range of $10-30 \mathrm{~cm}$ and $\mathrm{dbh}$ range of $2.5-10 \mathrm{~cm}$, respectively [56]. Trees and shrubs were marked, mapped and identified to species level. Height and diameter at breast height (dbh) were measured at $1.3 \mathrm{~m}$ for all trees and shrubs with $\mathrm{dbh}$ $\geq 2.5 \mathrm{~cm}$ including Liana. Liana diameter was measured at 130 $\mathrm{cm}$ above the highest root [28]. Leaf litter, defined as all nonliving biomass with a size greater than the limit for soil organic matter (suggested $2 \mathrm{~mm}$ ) and less than the minimum diameter chosen for dead wood (10 $\mathrm{cm}$ diameter in this study), was collected from a $1 \mathrm{~m}^{2}$ sub plot established in the $25 \mathrm{~m}^{2}$ subplots following Pearson et al. [56]. Total fresh weight was measured in the field; and a well-mixed sample of $100 \mathrm{~g}$ was placed in a marked plastic bag and taken to laboratory to determine moisture content and the total dry mass [56, 61]. Herbs, grasses and woody species that did not attain a dbh of $2.5 \mathrm{~cm}$ were destructively harvested by clipping all of them down to ground level within the $1 \mathrm{~m}^{2}$ subplots. Total fresh weight was recorded in the field and a $100 \mathrm{~g}$ well-mixed sample was taken to laboratory to determine total dry weight and moisture content [61].

Dead woods are important carbon sources and sinks [61]. Downed dead wood census was made using line-intersect methods [35]. Length and diameter of all downed dead woods with diameter $\geq 10 \mathrm{~cm}$ were recorded in a $5 \mathrm{~m}$ wide transect established in the main plot $\left(400 \mathrm{~m}^{2}\right)$. Downed dead woods were divided into sections of roughly $1 \mathrm{~m}$ and the exact length and diameter at the middle of each section were measured. For wood fragments that are less than $1 \mathrm{~m}$ long, the total length and diameter at the middle was measured [61]. Dead woods were grouped into decomposition classes following Pearson et al. [56] and samples were collected 
from each decomposition class for density (dry weight per volume) determination. Downed dead wood with a diameter $<10 \mathrm{~cm}$ were included to the litter layer. Soil samples were collected from the top $30 \mathrm{~cm}$ depth in the $1 \mathrm{~m}^{2}$ sub plots and composite samples were taken to laboratory. The soil samples were then ground to determine soil organic carbon concentration. In addition, a $30 \mathrm{~cm}$ depth core sampler with a diameter of $5 \mathrm{~cm}$ was used to take soil samples for bulk density determination.

\subsection{Estimation of Biomass and Carbon Stock}

\section{Live Trees}

The data obtained from tree measurement, litter, herb and grasses (LHG), dead wood and soil was recorded and organized on the excel data sheet. Trees were categorized into diameter classes ( $\geq 5 \mathrm{~cm}$ and between 2.5 and $5 \mathrm{~cm}$ ) in order to apply appropriate biomass estimation models. As site-specific multi species equations were not available, aboveground biomass of trees with $\mathrm{dbh} \geq 5 \mathrm{~cm}$ was estimated using the biomass equation formulated to estimate the aboveground biomass of tropical trees [15].

$$
\mathrm{Y}=0.0673 \times\left(\mathrm{gD}^{2} \mathrm{H}\right)^{0.976}
$$

Where, $\mathrm{Y}$ is aboveground biomass $(\mathrm{Kg}), \mathrm{g}$ : wood specific density $\left(\mathrm{g} / \mathrm{cm}^{3}\right)$, D: Diameter at Brest Height $(\mathrm{cm})$ and $\mathrm{H}$ : height $(\mathrm{m})$

Estimates of wood specific density were obtained from FDRE [22]. According to this source, the average wood density for woody species in Ethiopia was $0.612 \mathrm{~g} \mathrm{~cm}^{-3}$. This is comparable with the global average value and that of tropical Africa [58, 14, 37]. For a species whose wood specific density is missing, the genus average was used.

The above-ground biomass of small trees and shrubs with $2.5 \mathrm{~cm} \leq \mathrm{dbh}<5 \mathrm{~cm}$ was determined using the biomass model developed by Ali et al. [5].

$$
\operatorname{Ln}(A G B)=-3.50+1.65 \times \ln (D)+0.842 \times \ln (H)
$$

Where, $A G B=$ above-ground biomass [kg] of shrub and small trees; ln, natural logarithm; $\mathrm{H}$, total height (m); D, basal diameter of the longest stem $(\mathrm{cm})$

This model was preferred because it was formulated in similar climatic conditions with the current study area (warm and humid subtropical climate with a temperature ranging from 4.2 to $28.1^{\circ} \mathrm{C}$, and an average annual precipitation of $1374.7 \mathrm{~mm}$, most of which occurs between May and August) [5].

Palms possess very distinct growth pattern and internal anatomy from the common dicot trees [30]. Thus, a biomass model developed by Frangi and Lugo [25] was used in this study.

$$
\mathrm{B}_{\text {palm }}=4.5+(7.7 \times \mathrm{H})
$$

Where: $\mathrm{B}_{\text {palm: }}$ palm aboveground biomass $(\mathrm{kg})$ and $\mathrm{H}$ : Palm stem height

Lianas are important structural component of tropical forests, and contribute a lot to forest biomass, especially in liana infested forests [2]. Thus, liana aboveground biomass was estimated by the equation developed by Schnitzer et al. [60].

$$
\mathrm{AGB}=\exp [1.484+2.657 \times \ln (\mathrm{D})]
$$

Where, AGB: aboveground dry weight $(\mathrm{kg})$; D: diameter at $1.3 \mathrm{~m}$; ln: natural logarithm.

As belowground biomass estimation is difficult, time consuming and destructive [26], it was estimated based on the root to shoot ratio, assuming BGB constitutes $20 \%$ of the aboveground biomass [46].

$$
\mathrm{BGB}=\mathrm{AGB} \times 0.2
$$

Where, BGB: Belowground biomass, AGB: Aboveground biomass, 0.2: conversion factor (or $20 \%$ of AGB).

Above and belowground biomass was computed for each individual tree and sample plot, and presented on a hectare basis. The living biomass of trees was converted to $\mathrm{C}$ stock by multiplying it with the IPCC default fraction of 0.47 [39]. Carbon stock distribution pattern across size classes were computed and presented by d-d curve diagram based on $10 \mathrm{~cm} \mathrm{DBH}$ intervals for trees with a DBH of $5 \mathrm{~cm}$ and above.

\section{Dead wood}

The biomass of downed dead wood was estimated as a product of volume and wood density for each decomposition class by the equation given below [56]:

$$
B_{D D W}=\sum_{i=0}^{n} \Sigma V_{i} \times \rho
$$

Where, $\mathrm{B}_{\mathrm{DDW}}$ : Biomass of downed dead wood, $\Sigma \mathrm{V}_{\mathrm{i}}$ : Sum of volume of the $i^{\text {th }}$ dead wood and $\mathrm{g}$ : specific density per decomposition class.

The volume of downed dead wood was estimated as follows.

$$
V_{i}=\Pi * \frac{D i^{2}}{4} \times L_{i}
$$

Where, $\mathrm{V}_{\mathrm{i}}$ : volume of dead wood; $\mathrm{D}_{\mathrm{i}}$ : diameter of the dead wood; and $\mathrm{L}_{\mathrm{i}}$ : length of the dead wood.

The $\mathrm{C}$ stock of dead woods was obtained by multiplying the total dead wood biomass by the IPCC [39] default carbon fraction of 0.47 .

Leaf litter, herbs and grasses ( $L H G)$

Biomass of leaf litter, herbs, and grasses (LHG) was calculated using the following formula $[56,61]$.

$$
B=\left(\frac{\text { Total fresh } W t}{A} \times \frac{\text { Sample Dry } W t}{\text { Sample Fresh } W t}\right) \times 1 / 10,000
$$

Where B: LHG Biomass ( $\left.\mathrm{t} \mathrm{ha}^{-1}\right), \mathrm{A}$ : Subplot area, $\mathrm{W}_{\mathrm{t}}$ : weight

The loss on ignition (LOI) method was used to determine percent carbon in LHGs [6]. This method is a fast and inexpensive means of determining carbonate and organic contents. Accordingly, fresh weights of vegetative samples 
were dried at $70^{\circ} \mathrm{C}$ in the oven for 48 hours. Oven dried samples were placed on pre-weighted crucibles $\left(\mathrm{W}_{1}\right)$ and weighed together $\left(\mathrm{W}_{2}\right)$ and placed in the furnace at $550^{\circ} \mathrm{C}$ for ignition. The sample was removed from the furnace after one hour. The crucibles with ash were weighed after cooling $\left(\mathrm{W}_{3}\right)$ and then the percentage of carbon was calculated according to [6].

$$
\operatorname{Ash}(\%)=\left(\mathrm{W}_{3}-\mathrm{W}_{1}\right) /\left(\mathrm{W}_{2}-\mathrm{W}_{1}\right) \times 100
$$

$\mathrm{C}(\%)=(100-$ Ash $(\%)) \times 0.58(58 \%$ carbon in ash-free litter material) [65].

Where: C (\%): Carbon fraction in LHG biomass, $\mathrm{W}_{1}$ : weight of crucible, $\mathrm{W}_{2}$ : weight of the oven-dried sample and crucible, $\mathrm{W}_{3}$ : weight of ash and crucible.

The carbon stock of LHGs was calculated by multiplying biomass of LHGs per unit area with C (\%).

$$
\mathrm{C}_{\mathrm{LHG}}=\mathrm{B}_{\mathrm{LHG}} \times \mathrm{C}(\%)
$$

Where, $\mathrm{C}_{\mathrm{LHG}}$ : carbon stock in the leaf litter, herbs and grasses, $\mathrm{B}_{\mathrm{LHG}}$ : Biomass in the leaf litter, herbs and grasses, $\mathrm{C}$ (\%): carbon fraction determined in the laboratory [56].

Soil carbon

Soil organic carbon was calculated as recommended by Pearson et al. [56] from the depth, bulk density and C (\%).

$$
S O C=B D * d * C(\%)
$$

Where: SOC: soil organic carbon stock per unit area $(\mathrm{t} / \mathrm{ha})$; $\mathrm{BD}$ : soil bulk density $(\mathrm{g} / \mathrm{cm})$; d: the depth at which the sample was taken $(30 \mathrm{~cm})$ and $\mathrm{C}(\%)$ : Carbon concentration $(\%)$ was determined in the laboratory.

Bulk density of the soil sample was calculated as follows:

$$
B D=\frac{D_{w t}}{V}
$$

Where: BD: bulk density of the soil sample; $\mathrm{D}_{\mathrm{Wt}}$ : dry weight of soil sample; $\mathrm{V}$ : is volume of the soil sample in $\mathrm{cm}^{3}$.

Volume of the soil was computed using the following formula.

$$
V=h * \pi r^{2}
$$

Where, V: volume of the soil in the core sampler in $\mathrm{cm}^{3}$, h: height of core sampler in $\mathrm{cm}$, and r: radius of core sampler in $\mathrm{cm}$.

Total $\mathrm{C}$ stock of the forest was obtained by summing the $\mathrm{C}$ stocks of all carbon pools following Pearson et al. [56].

$$
\mathrm{C}_{\mathrm{t}}=\mathrm{AGC}+\mathrm{BGC}+\mathrm{C}_{\mathrm{LHG}}+\mathrm{C}_{\mathrm{DW}}+\mathrm{SOC}
$$

Where: $\mathrm{C}_{\mathrm{t}}$ : total carbon stock for all pools (ton/ha); AGC: Aboveground Carbon (ton/ha); BGC: Belowground Carbon (ton/ha); $\mathrm{C}_{\mathrm{LHG}}$ : Carbon in leaf litter, herb and grasses (ton/ha); $\mathrm{C}_{\mathrm{DW}}$ : Carbon in dead wood (ton/ha); SOC: Soil organic carbon (ton/ha).

\section{Result and Discussion}

\subsection{Carbon Stock Density in Different C pools}

This study investigated $\mathrm{C}$ stock densities of the 5 forest carbon pools, namely above and belowground biomass, dead wood, leaf litter, herbs and grasses (LHGs) and soil organic matter. Biomass $\mathrm{C}$ was calculated for 93 woody species including trees, shrubs and lianas in TLF. Result indicated that

\begin{tabular}{|c|c|c|c|c|c|c|c|c|c|}
\hline & AGB & BGB & AGC & BGC & $\mathrm{C}_{\text {LHG }}$ & $\mathbf{D W}_{\mathbf{B}}$ & $\mathbf{D W}_{\mathbf{C}}$ & SOC & TC \\
\hline Min & 26.19 & 4.835 & 42.31 & 8.27 & 1.13 & 0.000 & 0.000 & 46.39 & 145.37 \\
\hline Mean & 464.69 & 92.54 & 218.40 & 43.49 & 2.43 & 13.08 & 6.149 & 128.95 & 399.42 \\
\hline sd & 303.44 & 60.69 & 142.63 & 28.53 & 0.68 & 34.38 & 16.16 & 40.32 & 188.01 \\
\hline
\end{tabular}
the total carbon stock density of TLF was $399.42 \pm 188.01 \mathrm{t}$ ha $^{-1}$ (range: 145.37-886.23 t C ha $^{-1}$ ) (Table 1).

Table 1. Biomass and carbon stock ( $\mathrm{ha}^{-1}$ ) summary in various carbon pools of TLF. (AGB: Aboveground biomass; BGB: Belowground biomass; AGC: Aboveground carbon; BGC: Belowground carbon; $C_{L H G}$ : Leaf, herbs and grass carbon; DW $W_{B}$ Dead wood biomass; DW $:$ Dead wood carbon; SOC: Soil organic carbon; TC: Total carbon).

Among the 5 carbon pools, aboveground biomass stored the largest $(54.68 \%)$ portion of $\mathrm{C}$ in the forest out of which $214.86 \mathrm{t} \mathrm{C} \mathrm{ha}^{-1}$ was accumulated in trees with $\mathrm{dbh} \geq 5 \mathrm{~cm}$ (Table 2). This is in agreement with Mckinley et al. [48] in majority of $\mathrm{C}$ in tropical forests. The aboveground $\mathrm{C}$ (AGC)

\begin{tabular}{|c|c|c|c|}
\hline \multirow{2}{*}{ S/No } & \multirow{2}{*}{ Forest carbon pool } & \multicolumn{2}{|c|}{ Carbon content } \\
\hline & & t ha $^{-1}$ & Percent \\
\hline \multirow{4}{*}{1} & Tree with $\mathrm{dbh} \geq 5 \mathrm{~cm}$ & 214.86 & \multirow{4}{*}{54.68} \\
\hline & Shrub and small tree $2.5 \leq \mathrm{dbh}<5 \mathrm{~cm}$ & 0.99 & \\
\hline & Liana Carbon & 1.20 & \\
\hline & Palm Carbon & 1.35 & \\
\hline 2 & Belowground Biomass & 43.49 & 10.89 \\
\hline 3 & Leaf litter, herbs and grass (LHG) & 2.42 & 0.61 \\
\hline 4 & Dead wood & 6.15 & 1.54 \\
\hline 5 & Soil & 128.95 & 32.28 \\
\hline Total & & 399.42 & 100 \\
\hline
\end{tabular}
stock of TLF is within the range reported for closed tropical forests, i.e. less than 50 to $360 \mathrm{Mg} \mathrm{C} \mathrm{ha}^{-1}[12,13,43]$ and other similar studies in Ethiopia (30.8-414.7 $\left.\mathrm{t} \mathrm{C} \mathrm{ha}^{-1}\right)[4,52]$. which they indicated aboveground tree biomass stored the

Table 2. Proportion of carbon in various carbon pools of TLF. 
Although the proportional contribution of small trees depends on the successional stage of the stand, their contribution to the total forest carbon stock was little and thus are often neglected in forest $\mathrm{C}$ stock assessments [11]. Similarly, small trees and shrubs $(2.5 \mathrm{~cm} \leq \mathrm{dbh}<5 \mathrm{~cm})$ in the current study area consists of large number of individuals (132.33 stems ha ${ }^{-1}$ ), but their share to the total AGC was only $0.99 \mathrm{t} \mathrm{ha}^{-1}(0.46 \%)$. Other studies in Ethiopia and elsewhere also revealed that saplings, shrubs and other understory plants contributed only small fraction to the total forest $\mathrm{C}$ stock [13, 53]. The abundance of saplings and smaller trees suggest that TLF is in a secondary state of development. Sustainable management of small trees and saplings in secondary forests increase the amount of living biomass and $\mathrm{C}$ stock in subsequent years as trees and saplings grow [50]. As the proportion of secondary forests in the tropics is projected to increase due to increasing anthropogenic pressure, they are becoming important in global carbon cycle. Therefore, TLF can be recommended as a potential site for $\mathrm{REDD}^{+}$project in Ethiopia.

Palms are important components of tropical rainforest and present in all forest strata [62]. Out of ca. 2400 species of palms known in the world [32], 9 species exist in Ethiopia [19]. In this study area, however, only one species (Phoenix reclinata Jacq.) is recorded. Its AGC stock density was $1.35 \mathrm{t}$ $\mathrm{ha}^{-1}$. This value is greater than the value obtained for Eugeissona tristis (Palm) in Ayer Hitam Forest Reserve (Malaysia) with only $0.44 \mathrm{t} \mathrm{ha}^{-1}$ [62]. The overall result, however, is in agreement with the studies of de Castilho et al. [16]. The input of lianas to the total AGC of TLF was much lower $(0.55 \%)$ than that of tropical lowland forests where liana comprises $1-14 \%$ of the total live AGC [7, 27, 45]. The low proportion of liana $\mathrm{C}$ in this study area might be due to anthropogenic exploitation of lianas as these are widely used for fencing and house construction by the local people.

Compared to other forests in Ethiopia and elsewhere, TLF stored more C in its AGB than Humbo [4] and Anbessa forests [63] from Ethiopia; and Secondary and Gallery forests of Congo [18], Natural forests of Bangladesh [65] and Collaborative Forests in Nepal [47] (Table 3). But AGC stock density of TLF is much lower than Garjeda [63], Tara Gedam [52], Adaba-Dodola [53], Egdu [3], Low land areas of Simen Mountain National park [64], Arbaminch ground water forest [9] (all in Ethiopia), and Usambra and Uluguru forests [54] from Tanzania. The variation in AGC stock density between the current study area and other forests can be attributed to species composition, disturbance history, successional stage, climate, topography, edaphic factors and the allometric models used to calculate the AGB $[54,55,16,29]$. For instance, higher $\mathrm{C}$ stock density of Tara Gedam forest was associated to strict conservation through religious regulations [52] while that of Adaba-Dodola forest could be due to participatory forest management [53]. On the other hand, the higher AGC of Usambra and Uluguru forests was due to computational and sampling procedures [54].

Table 3. Comparison of TLF and other forests in Ethiopia and elsewhere with respect to Carbon stock $\left(t h a^{-1}\right)$.

\begin{tabular}{|c|c|c|c|c|c|c|c|c|}
\hline $\mathbf{S} / \mathbf{N}$ & Forest & AGC & BGC & SOC & DWC & LHGC & Total & Source \\
\hline 1 & Garjeda & 466.1 & 93.2 & 155.8 & - & 2.51 & 717.6 & \multirow{2}{*}{ Tamene Yohannes [63] } \\
\hline 2 & Anbessa & 169.0 & 33.8 & 149.6 & - & 1.15 & 353.6 & \\
\hline 3 & Adaba-Dodola community forest & 278.0 & 41.8 & 186.4 & - & 1.06 & 507.3 & Muluken Nega et al. [53] \\
\hline 4 & Egdu & 278.1 & 55.6 & 277.6 & - & 3.47 & 614.7 & Adugna Feyisa et al. [3] \\
\hline 5 & Natural forests of Bangladesh & 111.4 & - & 168.2 & - & 4.21 & 283.8 & Ullah \& Al Amin [65] \\
\hline 6 & Collaborative Forests in Terai (Nepal) & $116.7-178.9$ & - & - & - & - & - & Mandal et al. [47] \\
\hline 8 & Lowland Area of Simien Mountains National Park & 270.9 & 54.2 & 242.5 & 0.7 & 0.02 & 568.3 & Tibebu Yelemfrhat et al. [64] \\
\hline 9 & Humbo & 30.8 & 14.5 & 168.2 & - & 12.6 & 225.9 & Alefu Chinasho et al. [4] \\
\hline 10 & Arba Minch Ground Water Forest & 414.7 & 83.5 & 83.8 & - & 1.3 & 583.2 & Belay Melese et al. [9] \\
\hline 11 & Tara Gedam forest & 306.4 & 61.5 & 274.3 & - & 0.9 & 643.1 & $\begin{array}{l}\text { Mohammed Gedefaw et al. } \\
{[52]}\end{array}$ \\
\hline 12 & Mount Zequalla Monastery forest & 237.8 & 47.6 & 57.6 & - & 6.5 & 349.5 & Abel Girma et al. [1] \\
\hline 13 & Tropical seasonal forest in Southwestern China & 163.0 & 38.8 & 91.1 & 9 & 1.4 & 303.3 & Lu et al. [45] \\
\hline 15 & Uluguru & 318 & 70 & 295 & - & - & & Munishi [54] \\
\hline 16 & Tulu Lafto & 218.4 & 43.5 & 128.9 & 6.2 & 2.4 & 399.4 & Current study \\
\hline
\end{tabular}

In TLF, soil was the $2^{\text {nd }}$ largest $\mathrm{C}$ pool with $128.95 \mathrm{t} \mathrm{C}^{-1}$ $(32.28 \%)$ stored in the upper $30 \mathrm{~cm}$ depth. This is within the range estimated for tropical moist and seasonal forests [13]. TLF stored more carbon in its soil than other forests such as Mount Ziquala [1] and Arbaminch Ground water forests [9] but much lower than Usambra and Uluguru forests [54] may be due to the difference in vegetation types, topography, natural and anthropogenic disturbances, soil type, and land use history [40]. Though most studies outside Ethiopia included the upper $1 \mathrm{~m}$ layer of the soil profile and comparison is not feasible, soil $\mathrm{C}$ in the present study area is higher than that of Tropical seasonal forest in Southwestern China [45].

Belowground biomass, dead wood and leaf litter, herbs and grasses (LHGs) contributed the remaining 13\% C in TLF (Table 2). Dead wood accounts for $10-20 \%$ of AGC in mature forests $[36,57,49]$, but it contributed only $2.82 \%$ of the AGC and $1.54 \%$ of the total $\mathrm{C}$ in the current study area. 
In terms of dead wood C stock, TLF is less than other tropical forests $[45,55,57]$ except the Lowland area of Simien Mountains National Park in Ethiopia [64]. The low dead wood carbon in the study area could be attributed to fuel wood collection by the surrounding people, forest fire that convert all the dead wood into ashes and the rapid decomposition rate associated to tropical climate.

Leaf litter, herbs and grasses (LHG) comprised the least proportion of carbon stock $(0.56 \%)$ in TLF. It is comparable to the value reported for Garjeda forest [63]; but greater than that of Tropical seasonal forest in Southwestern China [45], Tara Gedam [52], Arbaminch ground water [9], Low land areas of Simen Mountain [64], Adaba Dodola [53] and Anbessa forests [63].

Carbon stock density along DBH classes

Size class distributions such as diameter class are considered as an important indicator of forest dynamics and determine a number of ecosystem functions in a forest. This study revealed that total stem density (trees with a diameter $\geq 5 \mathrm{~cm}$ ) decreased with increasing diameter asserting an inverted-J population curve (Figure $3 \mathrm{a}$ ). Such population structure indicates good reproduction and healthy regeneration. The distribution of $\mathrm{C}$ stock along dbh classes, however, revealed an irregular shape with maximum $\mathrm{C}$ accumulated in the middle (from $35-55 \mathrm{~cm}$ ) and last $(>105$ $\mathrm{cm}$ ) dbh classes (Figure $3 \mathrm{~b}$ ) which is due to abundance of medium sized trees typical of Combretum-Terminalia woodland vegetation type (CTW) and large tree size in the last diameter classes. This asserts that higher diameter trees are important reservoirs of biomass $\mathrm{C}$ and removal of these trees from the forest would release large amount of $\mathrm{C}$ to the atmosphere in the form of $\mathrm{CO}_{2}$.

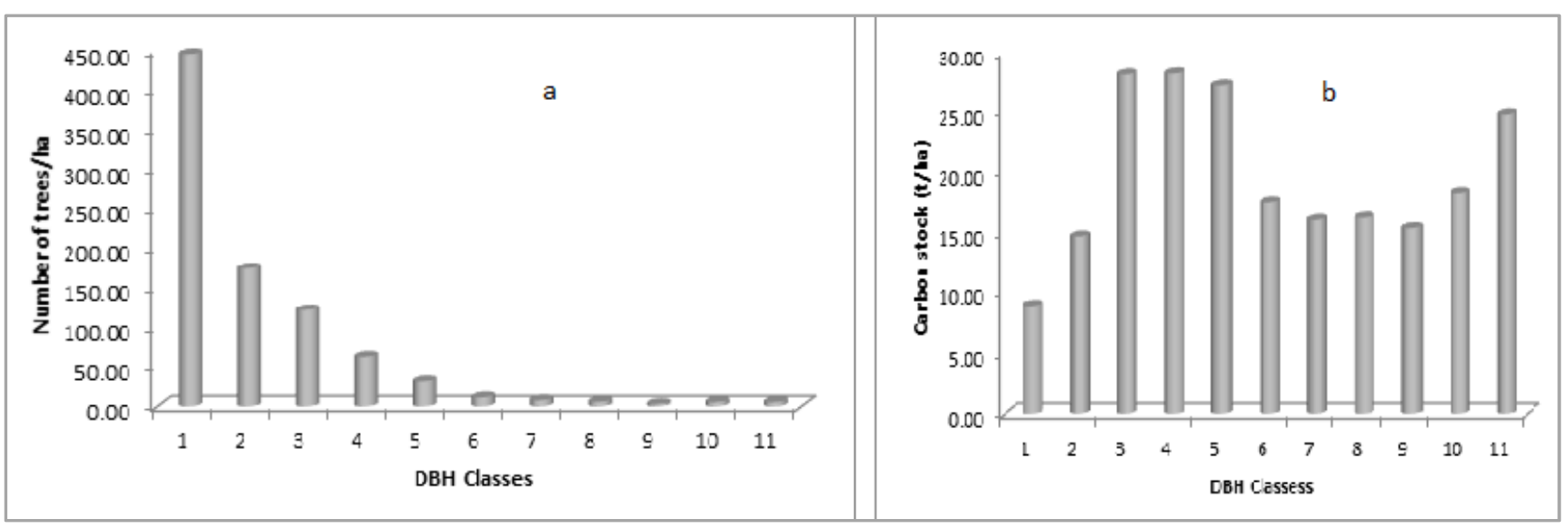

Figure 3. Stem density (a) and C stock distribution (b) along DBH Classes in TLF.

DBH Classes: 1: 5.00-15.00 cm; 2: 15.01-25.00 cm; 3: 25.01-35.00 cm; 4: 35.01-45.00 cm; 5: 45.01-55.00 cm; 6: 55.01-65.00 cm; 7: 65.01-75.00 cm; 8: 75.01-85.00 cm; 9: 85.01-95.00 cm; 10: 95.01-105.00 $\mathrm{cm}$ and $11:>105 \mathrm{~cm}$.

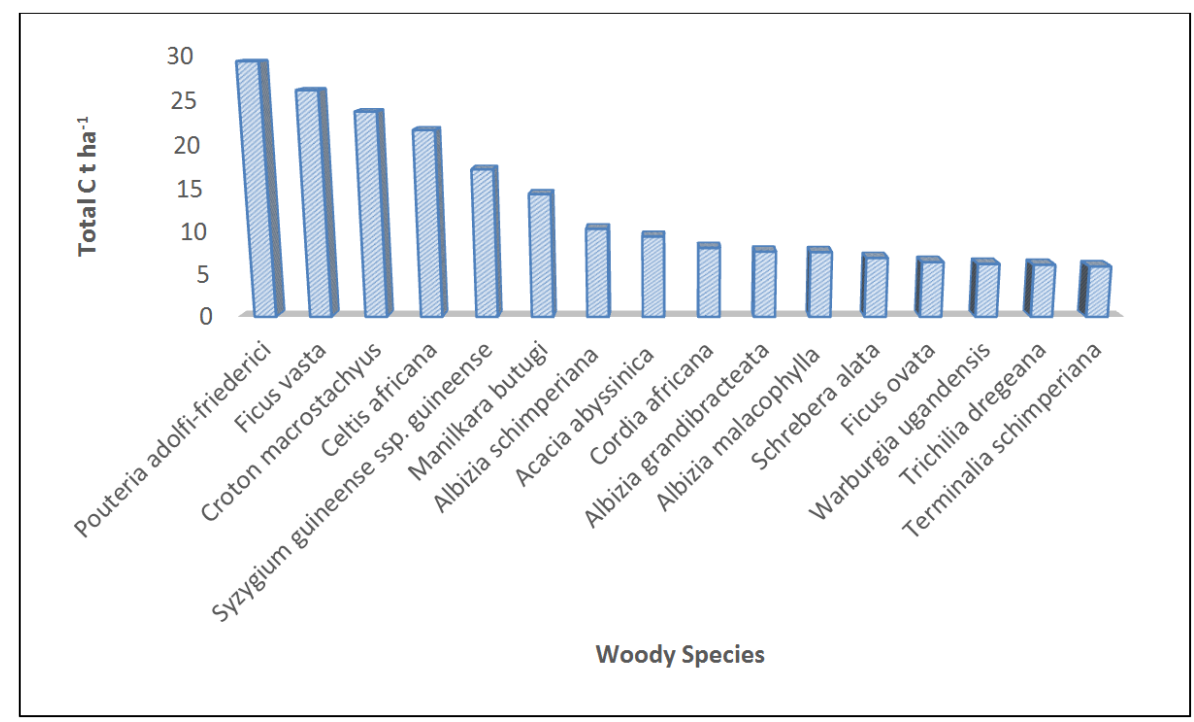

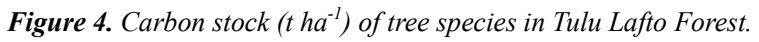

\subsection{Carbon Stock density of Tree Species in Tulu Lafto Forest}

Tree species differ in terms of their carbon content. Out of the 93 woody species in TLF, ca. $80 \%$ of the living $\mathrm{C}$ was stored in only 16 tree species (Figure 4) indicating interspecific variation in $\mathrm{C}$ stock. Two tree species that were 
well represented by large sized individuals namely, Pouteria adolfi-friederici (with larger mean height) and Ficus vasta (larger mean diameter), stored more than $20 \%$ of biomass C in the forest. Croton macrostachyus, Celtis africana and Syzyguim guineense ssp. guineense with 9.16, 8.36 and $6.65 \%$, respectively are also important $\mathrm{C}$ reservoirs in TLF. Previous studies in Ethiopia and elsewhere also confirmed the dominance of few tree species in terms of above and belowground $\mathrm{C}$ stock. For example, $90 \%$ of the total $\mathrm{C}$ in the living biomass of Adaba Dodola community forest was stored in only two tree species (Juniperus procera and Podocarpus falcatus) [53]. Similarly, Dipterocarpus turbinatus was indicated to dominate both above and belowground $\mathrm{C}$ stock of natural forests in Bangladesh [65]. Thus, conservation of tree species with larger biomass $\mathrm{C}$ in

Aboveground carbon

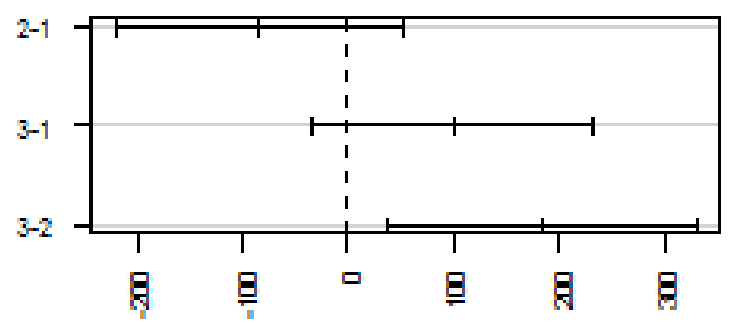

Differences in mean levels of as. factor(ClusterID)

Soil organic carbon

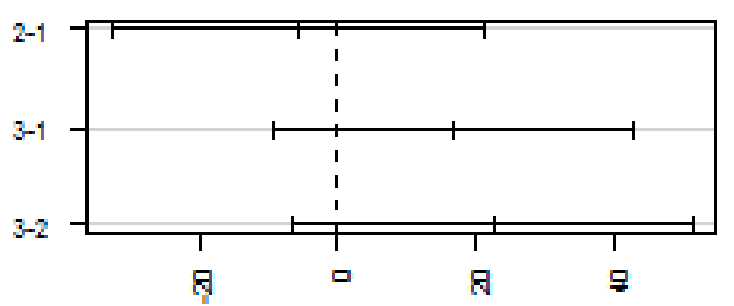

Differences in mean levels of as. factor(ClusterlD)

Leaf, Herb, Grass carbon

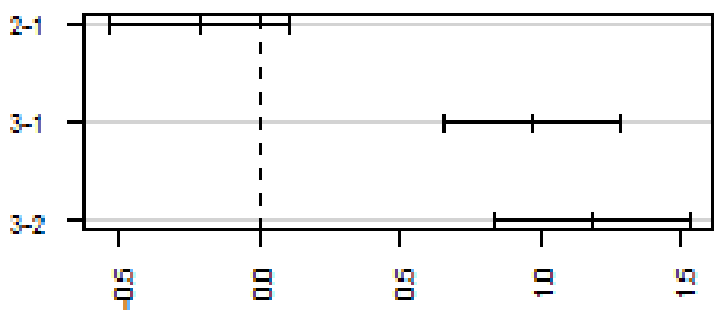

Differences in mean levels of as. factor(ClusterID) the forest would contribute to the efforts of reducing emission from deforestation and forest degradation.

\subsection{Carbon Stock Variation Among Vegetation Units}

Vegetation units in TLF showed significant difference in total $\mathrm{C}$, aboveground $\mathrm{C}$, belowground $\mathrm{C}$ and $\mathrm{C}$ stock of leaf litter, herbs and grasses (LHG), but not in soil and dead wood carbon (Figure 5). Clusters on the opposite sides of the dotted line and not overlapping it are significantly different from one another. The Afromontane type vegetation unit occupying higher altitude accumulated significantly higher $\mathrm{C}$ than the remaining two vegetation units. The Riverine and Combretum-Terminalia woodland types did not show significant difference with respect to total C.

\section{Belowground carbon}

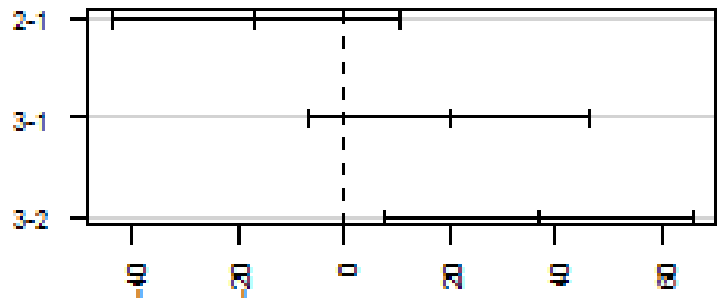

Differences in mean levels of as.factor(ClusterlD)

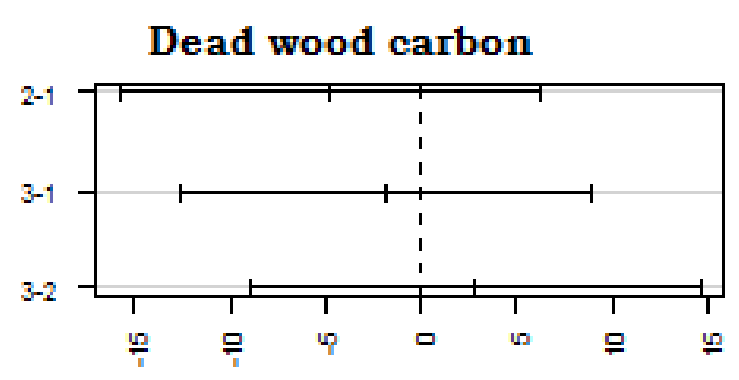

Differences in mean levels of as. factor(ClusterlD)

Numbers on the left indicate vegetation units 1: Riverine type; 2: Combretum-Terminalia woodland type; 3: Afromontane forest type vegetation units.

Figure 5. Pairwise comparison of vegetation units in terms of carbon stock density. 
Documenting within forest $\mathrm{C}$ stock variation is vital in monitoring change in global $\mathrm{C}$ stock. $\mathrm{C}$ stock varies within sites due to variation in topographic features and floristic composition, disturbance history, successional stage and soil fertility [55]. The variation in $\mathrm{C}$ stock density between vegetation units of this study area could be attributed to a number of interacting environmental factors, including: topography, edaphic factors and species composition. For instance, the higher $\mathrm{C}$ stock density of the Afromontane type vegetation unit in this study area is due to minimal human impact at higher elevation that maintained abundant big sized trees.

Results of this study showed the highest dead wood C stock density in Riverine type vegetation unit may be because of: (1) moist microclimate around river valley that protected dead woods from the devastating effect of forest fire; (2) the steep slope around rivers that hindered the surrounding people from collecting dead woods for fuel and other purposes; and (3) increased rate of tree fall on steep slope of riverine areas [10]. In contrast, dead wood carbon stock was the lowest in Combretum-Terminalia type vegetation units which might be due to forest fire that consumes the dead wood, or fuelwood collection by the local people as this vegetation unit is easily accessible. Fuelwood constitutes the only available source of energy for household utilization by the surrounding people. Fuelwood constitute the largest component of biomass loss in many developing countries [39].

\section{Conclusion and Recommendation}

Forests sequester and store more carbon than any other terrestrial ecosystems [29]. Hence, conserving remnant forest patches and maintaining its $\mathrm{C}$ stocks while promoting greater $\mathrm{CO}_{2}$ uptake has gained much attention as an option to mitigate the impact of climate change [21]. Though the C stock of TLF is lower than some other forests in Ethiopia, substantial amount of carbon is stored in its aboveground biomass and soil. However, increasing frequency of disturbances due to farmland expansion, livestock grazing, logging and other anthropogenic activities will likely threaten the sustainability of TLF and its C stock. As per this study, more than $60 \%$ of trees in TLF are less than $15 \mathrm{~cm} \mathrm{DBH}$ asserting that the forest is in a secondary state of development. The abundance of young trees in the forest indicates a high potential of $\mathrm{C}$ sequestration as they rapidly grow and accumulate more $\mathrm{C}$ in the future. Hence, appropriate forest conservation strategies including enrichment planting should be done in order to conserve the existing $\mathrm{C}$ stock and enhance further $\mathrm{C}$ sequestration in the forest. In addition, integrating the $\mathrm{C}$ sequestration potential of this forest with the international initiatives such as $\mathrm{REDD}^{+}$could supplement the national forest conservation efforts in the future. Finally, site-specific $\mathrm{C}$ stock studies should be promoted than using regional and national average values that fail to account local variability. Regional and national average data tend to underestimate forest $\mathrm{C}$ stocks as compared to site specific studies.

\section{References}

[1] Abel Girma, Teshome Soromessa and Tesfaye Bekele (2014). Forest Carbon Stocks in Woody Plants of Mount Zequalla Monastery and its Variation along Altitudinal Gradient: Implication of Managing Forests for Climate Change Mitigation. Sci. Technol. Arts Res. J. 3 (2): 132-140.

[2] Addo-Fordjour, P. and Rahmad, Z. B. (2013). Mixed Species Allometric Models for Estimating above-Ground Liana Biomass in Tropical Primary and Secondary Forests, Ghana. ISRN Forestry. http://dx.doi.org/10.1155/2013/153587.

[3] Adugna Feyissa, Teshome Soromessa, Mekuria Argaw (2013). Forest Carbon Stocks and Variations along Altitudinal Gradients in Egdu Forest: Implications of Managing Forests for Climate Change Mitigation. Sci. Technol. Arts Res. J. 2 (4): $40-46$.

[4] Alefu Chinasho, Teshome Soromessa, Eyale Bayable (2015). Carbon Stock in Woody Plants of Humbo Forest and its Variation along Altitudinal Gradients: The Case of Humbo District, Wolaita Zone, Southern Ethiopia. International Journal of Environmental Protection and Policy 3 (4): 97-103.

[5] Ali, A., Xu, M. S., Zhao, Y. T., Zhang, Q. Q., Zhou, L. L., Yang, X. D., Yan, E. R. (2015). Allometric (biomass equations for shrub and small tree species in subtropical China. Silva Fennica 49 (4): 1-10.

[6] Allen, S. E., Grimshaw, H. M. and Rowland, A. P. (1986): Chemical Analysis. In: Methods in Plant Ecology, pp. 285344 (Moore P. D. and Chapman, S. B. eds). Blackwell Scientific Publications, Boston.

[7] Alves, F. L., Assis, M. A., van Melis, J., Barros, A. L. S., Vieira, S. A., Martins, F. R., Luiz A. Martinelli, L. A. and Joly, C. A. (2011). Variation in liana abundance and biomass along an elevational gradient in the tropical Atlantic Forest (Brazil). Ecol Res. 1-10.

[8] Baccini, A., Larporte, N., Goetz, S. J., Sun, M. and Dong, H. (2008). A first map of tropical Africa's aboveground biomass derived from satellite imagery. Environmental Research Letters 3: 1-9.

[9] Belay Melese, Ensermu Kelbessa, Teshome Soromessa (2014). Forest Carbon Stocks in Woody Plants of Arba Minch Ground Water Forest and its Variations along Environmental Gradients. Sci. Technol. Arts Res. J. 3 (2): 141-147.

[10] Bianchini, E., Pimenta, J. A. and dos Santos, F. A. M. (2011). Spatial and Temporal Variation in the Canopy Cover in a Tropical Semi-Deciduous Forest. Brazilian Archives of Biology and Technology 44 (3): 269 - 276.

[11] Brown, S. (2002). Measuring carbon in forests: current status and future challenges. Environmental Pollution 116: 363-372.

[12] Brown, S., Gillespie, A. and Lugo, A. E., (1989). Biomass estimation methods for tropical forests with applications to forest inventory data. Forest Sci. 35: 881-980.

[13] Brown, S., Iverson, L. R., Prasad, A. and Liu, D. (1993). Geographical distribution of carbon in biomass and soils of tropical Asian forests. Geocarto International 4: 45-59. 
[14] Chave, J., Muller-Landau, H. C., Baker, T. R., Easdale, T. A., Steege, H. T. and Webb, C. O. (2006). Regional and phylogenetic variation of wood density across 2456 Neotropical tree species. Ecological Applications 16 (6): 2356-2367.

[15] Chave, J., Rejoum-Echain, M., Burquez, A., Chidumayo, E., Colgan, M. S., Delitti, W. B. C., Duque, A., Eid, E., Fearnside, P. M., Goodman, R. C., Henry, M., Zyrizar, A. M., Mugasha, W. A., Muller-Landau, H. C., Mencuccini, M., Nelson, B. W., Ngomanda, A., Nogueira, E. M., Ortiz-Malavassi, E., Peli, S. S. I., Er, R., Ploton, P., Ryan, C. M., Saldarriaga, J. G. and Vieilledent, G. (2014). Improved allometric models to estimate the aboveground biomass of tropical trees. Global Change Biology 20: 3177-3190.

[16] de Castilho, C. V., Magnusson, W. E., de Arau'jo, R. N. O., Luiza ${ }^{2}$, R. C. C., Luiza o, F. J., Lima, A. P. and Higuchi, N. (2006). Variation in aboveground tree live biomass in a central Amazonian Forest: Effects of soil and topography. Forest Ecology and Management 234: 85-96.

[17] DeFries, R., F., Achard, S., Brown, M., Herold, D., Murdiyarso, B., Schlamadinger, C., de Souza, J. (2006). Reducing greenhouse gas emissions from deforestation in developing countries: considerations for monitoring and measuring. GOFC-GOLD Report No. 26.

[18] Ekoungoulou, R., Liu, X., Ifo, S. A., Loumeto, J. J., Folega, F. (2014). Carbon Stock Estimation in Secondary Forest and Gallery Forest of Congo using Allometric Equations. International journal of scientific \& technology research 3 (3): 465-474

[19] Edwards, S., Sebsebe Demissew and Hedberg, I. (eds.) (1997). Flora of Ethiopia \& Eritrea Vol. 6. Hydrocharitaceae to Arecaceae. Addis Ababa, Ethiopia and Uppsala, Sweden. Pp. 586.

[20] FAO (2010). Global Forest Resources Assessment 2010: Main report. Rome, Italy. Pp. 340.

[21] FAO (2012). State of the world's forests. Rome, Italy. Pp. 46.

[22] FDRE (2016). Ethiopia's forest reference level submission to the UNFCCC. Addis Ababa, Ethiopia. Pp. 52.

[23] Federici, S., Francesco, N., Tubiello, F. N., Salvatore, M., Jacobs, H., Schmidhuber, J. (2015). New estimates of $\mathrm{CO}_{2}$ forest emissions and removals: 1990-2015. Forest Ecology and Management 352: 89-98.

[24] Fischer, R., Ensslin, A., Rutten, G., Fischer, M., Costa, D. S. and Kleyer, M. (2015). Simulating Carbon Stocks and Fluxes of an African Tropical Montane Forest with an IndividualBased Forest Model. PLoS ONE 10 (4): 1-13.

[25] Frangi, J. and Lugo, A. (1985). Ecosystem dynamics of subtropical floodplain forest. Ecological Monographs 55: 352369.

[26] Geider, R. J., Delucia, E. H., Falkowski, P. G., Finzi, A. C., Grime, J. P., Grace, J., Kana, T. M., LaRoche, J., Long, S. P., Osborne, B. A., Platt, T., Prentice, I. C., Raven, J. A., Schlesinger, W. H., Smetacek, V., Stuart, V., Sathyendranath, S., Thomas, R. B., Vogelmann, T. C., Williams, P. and Woodward, F. I. (2001). Primary Productivity of Planet Earth: Biological Determinants and Physical Constraints in Terrestrial and Aquatic Habitats. Global Change Biol. 7: 849882.
[27] Gerwing, J. J. and Farias, D. L. (2000). Integrating liana abundance and forest stature into an estimate of total aboveground biomass for an eastern Amazonian forest. Journal of Tropical Ecology 16: 327-335.

[28] Gerwing, J. J., Schnitzer, S. A., Burnham, R. J., Bongers, F., Chave, J., DeWalt, S. J., Ewango, C. E. N., Foster, R., Kenfack, D., Martinez-Ramos, M., Parren, M., Parthasarathy, N., P'erez-Salicrup, D. R., Putz, F. E., Thomas, D. W. (2006). A Standard Protocol for Liana censuses. Biotropica 38 (2): 256-261.

[29] Gibbs, H. K., Brown, S., Niles, J. O., Foley, J. A. (2007). Monitoring and estimating tropical forest carbon stocks: making REDD a reality. Environmental Research Letters 2: 113

[30] Goodman, R. C., Phillips, O. L., Torres, D., Freitas, L., Cortese, S. T., Monteagudo, A., Baker, T. R. (2013). Amazon palm biomass and allometry. Forest Ecology and Management, 310: 994-1004.

[31] Gorte, R. W. (2007). Carbon Sequestration in forests. Congressional Research Services (CRS) Order Code RL31432. Pp. 25.

[32] Govaerts, R., Dransfield, J. (2005). World checklist of Palms. Royal Botanic Gardens, Kew, Richmond, UK.

[33] Habtamu Asaye (2014a). Determination of conservation Benefits and carbon sequestration capacity of the Awash National Park of Ethiopia. Addis Ababa, Ethiopia. Pp. 37.

[34] Habtamu Asaye (2014b). Determination of conservation Benefits and carbon sequestration potential of the Simien Mountain National Park of Ethiopia. Addis Ababa, Ethiopia. Pp. 47.

[35] Hairiah, K., Sitompul, S. M., Noordwijk, M., Palm, C. (2001). Methods for sampling carbon stocks above and below ground. International Centre for Research in Agroforestry (ICRAF). Southeast Asian Regional Research Programme, Bogor, Indonesia, Pp. 23.

[36] Harmon, M. E. Brown, S. and Gower, S. T. (1993). Consequences of tree mortality to the global carbon cycle. In: Carbon Cycling in Boreal and Subarctic Ecosystems, Biospheric Response and Feedbacks to Global Climate Change, pp. 167-176. (Vinson, T. S. and Kolchugina, T. P. eds.). Symposium Proceedings. USEPA, Corvallis.

[37] Henry, M., Besnard, A., Asante, W. A., Eshun, J., Adu-Bredu, S., Valentini, R., Bernoux, M., Saint-André, L. (2010). Wood density, phytomass variations within and among trees, and allometric equations in a tropical rainforest of Africa. Forest Ecology and Management 260: 1375-1388.

[38] Houghton, R. A. (2005). Aboveground Forest Biomass and the Global Carbon Balance. Global Change Biology 11: 945958 .

[39] IPCC (2006). Guidelines for National Greenhouse Gas Inventories, Prepared by the National Greenhouse Gas Inventories Programme, Eggleston, H. S., Buendia, L., Miwa, K., Ngara, T. and Tanabe, K. (eds). IGES, Japan.

[40] Jobbagy, E. G. and Jackson, R. B. (2000). The Vertical distribution of Soil Organic Carbon and its relation to Climate and Vegetation. Ecological Applications 10 (2): 423-436. 
[41] Kauppi, P. and Sedjo, R. (2001). Technological and Economic Potential of options to Enhance, Maintain, and Manage Biological Carbon Reservoirs and Geo-engineering. In: Climate Change 2001: Mitigation, pp. 301-344. (Metz, B., Davidson, O., Swart, R. and Pan, J., eds.). Contribution of Working Group III to the Third Assessment Report of the IPCC. Cambridge University Press, Cambridge, UK.

[42] Köhl, M., Lasco, R., Cifuentes, M., Jonsson, Ö., Korhonen. K. T., Mundhenk, P., Navar, J. J., Stinson, G. (2015). Changes in forest production, biomass and carbon: Results from the 2015 UN FAO Global Forest Resource Assessment. Forest Ecology and Management 352: 21-34.

[43] Lasco, R. D. (2002). Forest carbon budgets in Southeast Asia following harvesting and land cover change. Science in China (Series C) 45: 55-64.

[44] Lewis, S. L., Lopez-Gonzalez, G., Sonke', B., Affum-Baffoe, K., Baker, T. R., Ojo, L. O., Phillips, O. L., Reitsma, J. M., White, L., Comiskey, J. A., Marie-Noe"1, D. K., Ewango, C. E. N., Feldpausch, T. R., Hamilton, A. C., Gloor, M., Hart, T., Hladik, A., Lloyd, J., Lovett, J. C., Makana, J., Malhi, Y., Mbago, F. M., Ndangalasi, H. J., Peacock, J., Peh, K. S. H., Sheil, D., Sunderland, T., Swaine, M. D., Taplin, J., Taylor, D., Thomas, S. C., Votere, R. and Wo"1l, H. (2009). Increasing carbon storage in intact African tropical forests. Nature 457: 1003-1006.

[45] Lü, X., Tang, J., Zhi-Li Feng, Z. and Li, M. (2009). Diversity and aboveground biomass of lianas in the tropical seasonal rain forests of Xishuangbanna, Southwest China. Int. J. Trop. Biol. 57 (1-2): 211-222

[46] MacDicken, K. G. (1997). A Guide to Monitoring Carbon Storage in Forestry and Agro-forestry Projects. Winrock International Institute for Agricultural Development, Arlington, Virginia. Pp. 87.

[47] Mandal, R. A., Dutta, I. C., Jha, P. K., Karmacharya, S. (2013) Relationship between Carbon Stock and Plant Biodiversity in Collaborative Forests in Terai, Nepal. ISRN Botany, 1-7. http://dx.doi.org/10.1155/2013/625767.

[48] Mckinley, D. C., Ryan, M. G., Birdsey, R. A., Giardina, C. P., Harmon, M. E., Heath, L. S., Houghton, R. A., Jackson, R. B., Morrison, J. F., Murray, B. C., Pataki, D. E., Skog, K. E. (2011). A synthesis of current knowledge on forests and carbon storage in the United States. Ecological Applications 21 (6): 1902-1924.

[49] Meriem, S., Tjitrosoedirjo, S., Kotowska, M. M., Hertel, D., Triadiati T. (2016). Carbon and nitrogen stocks in dead wood of tropical lowland forests as dependent on wood decay stages and land-use intensity. Ann. For. Res. 59 (2): 299-310.

[50] Missanjo, E. and Kamanga-Thole, G. (2015). Estimation of Biomass and Carbon stock for Miombo Woodland in Dzalanyama Forest reserve, Malawi. Research Journal of Agriculture and Forestry Sciences, Vol. 3 (3): 7-12,

[51] Miura, S., Amacher, M., Hofer, T., Ayanz, J. S., Ernawati, Thackway, R. (2015). Protective functions and ecosystem services of global forests in the past quarter-century. Forest Ecology and Management 352: 35-46.

[52] Mohammed Gedefaw, Teshome Soromessa, Belliethathan, S. (2014). Forest Carbon Stocks in Woody Plants of Tara Gedam Forest: Implication for Climate Change Mitigation. Sci. Technol. Arts Res. J. 3 (1): 101-107.
[53] Muluken Nega, Teshome Soromessa, Eyale Bayable (2015). Carbon stock in Adaba-Dodola community forest of Danaba district, West Arsi zone of Oromia region, Ethiopia: An implication for climate change mitigation. Journal of Ecology and Natural Environment 7 (1): 14-22.

[54] Munishi, P. K. T. (2004). Carbon storage in Afromontane Rain forests of the eastern arc mountains of Tanzania: Their net contribution to atmospheric carbon. Journal of Tropical Forest Science, 16 (1): 78-93.

[55] Ngo, K. M., Turner, B. L., Muller-Landau, H. C., Davies, S. J., Larjavaara, M., Hassan, N. F. N., Lum, S. (2013). Carbon stocks in primary and secondary tropical forests in Singapore. Forest Ecology and Management 296: 81-89.

[56] Pearson, T. R., Walker, S., Brown, S. (2005). Source book for land-use, land-use change and forestry projects. Winrock International and the Bio-carbon fund of the World Bank. Arlington, USA, Pp. 57.

[57] Pfeifer, M., Lefebvre, V., Turner, E., Cusack, J., Khoo, M., Chey, V. K., Peni, M. and Ewers, R. M. (2015). Deadwood biomass: an underestimated carbon stock in degraded tropical forests? Environ. Res. Lett. 10: 1-11.

[58] Reyes, G., Brown, S., Chapman, J. and Lugo, A. E. (1992). Wood densities of tropical tree species: General Technical report. U.S. Department of Agriculture, New Orleans, USA. Pp. 15.

[59] Romijn, E., Herold, M., Kooistra, L., Murdiyarso, D. and Verchot, L. (2012). Assessing capacities of non-Annex I countries for national forest monitoring in the context of REDD $^{+}$. Environmental Science \& Policy 19-20: 33-48.

[60] Schnitzer, S. A., DeWalt, S. J., Chave, J. (2006). Censusing and measuring lianas: a quantitative comparison of the common methods, Biotropica 38 (5): 581-591, 2006.

[61] Subedi, P., B., Shankar, P., S. Pandey, A., Rana, B., E., Bhattarai, S., Banskota, T., R., Charmakar, S., and Tamrakar, R. (2010). Forest Carbon Stock Measurement: Guidelines for measuring carbon stocks in community-managed forests. Asia. Pp. 69.

[62] Syafinie, A. M., Ainuddin, A. N. (2013). Biomass and Carbon Estimation of Eugeissona tristis. Sains Malaysiana 42 (10): 1461-1466.

[63] Tamene Yohannes (2016). Plant Diversity and Carbon Stock Analysis along Environmental Gradients: the case of Gergeda and Anbessa Forests in Western Ethiopia. PhD Dissertation. Addis Ababa University, Ethiopia. Pp. 183.

[64] Tibebu Yelemfrhat, Teshome Soromessa, Eyale Bayable (2014). Forest Carbon Stocks in Lowland Area of Simien Mountains National Park: Implication for Climate Change Mitigation. Sci. Technol. Arts Res. J. 3 (3): 29-36.

[65] Ullah, M. R. and Al-Amin, M. (2012). Above- and belowground carbon stock estimation in a natural forest of Bangladesh. Journal of forest science 58 (8): 372-379.

[66] Watson, C., Mourato, S. and Milner-Gulland, E. J. (2013). Uncertain Emmision reduction from Forest conservation: REDD in the Bale Mountains, Ethiopia. Ecology and Society $18(3): 1-16$.

[67] Yitebitu Moges, Zewdu Eshetu and Sisay Nune (2010). Ethiopian forest resources: current status and future management options in view of access to carbon finances. Addis Ababa, Ethiopia. Pp. 54. 